\title{
SIFAT FISIK DAN KIMIA EDIBLE FILM PATI UMBI GADUNG PADA BERBAGAI KONSENTRASI
}

\section{PHYSICAL AND CHEMICAL PROPERTIES THE EDIBLE FILM OF STARCH GADUNG VARIOUS CONSENTRATIONS}

\author{
Mohammad Deden ${ }^{1}$, Abdul Rahim ${ }^{2}$, Asrawaty $^{1 *}$ \\ ${ }^{1}$ Program Studi Teknologi Hasil Pertanian, Fakultas Pertanian, Universitas Alkhairaat, \\ Jl. Diponegoro No. 39, Palu 94221, Indonesia \\ ${ }^{2}$ Fakultas Pertanian Universitas Tadulako, Jl. Soekarno Hatta Km 9, Palu 94118, Indonesia
}

\begin{abstract}
ABSTRAK
Masa ini penggunaan polimer sintetik sebagai plastik memiliki peran penting bagi ekonomi masyarakat industri modern. Kemasan plastik sering dimanfaatkan sebagai bahan pengemas makanan. Namun, penggunaan plastik dapat mencemari lingkungan, karena plastik sulit didegradasi secara alami. Salah satu alternatif mengganti penggunaan plastik konvensional sebagai kemasan makanan adalah plastik berbahan alam yang mudah didegradasi (biodegradable plastic) yang disebut edible film. Penggunaan pati umbi gadung sebagai bahan baku pembuatan edible film tidak akan mengganggu kestabilan pangan, karena gadung tidak dikonsumsi seperti beras, jagung dan singkong. Umbi gadung sangat baik digunakan untuk bahan polimer edible film mengandung karbohidrat yang cukup tinggi. Bertujuan untuk mengetahui sifat fisik dan kimia edible film pati umbi gadung pada perbagai konsentrasi. Simpulan kondisi optimum pada pembuatan edible film yang baik pada konsentrasi pati gadung $6 \%$ dengan KA $11,50 \%$ dan ketebalan rerata $0,13 \mathrm{~mm}$.
\end{abstract}

Kata kunci: pati gadung; edible film; sifat fisik dan kimia; konsentrasi

\begin{abstract}
Today, the use of synthetic polymers as plastics has an important role in the economy of modern industrial society. Plastic packaging is often used as a food packaging material. However, the use of plastics can pollute the environment, because plastic is difficult to degrade naturally. One alternative to replacing the use of conventional plastics as food packaging is biodegradable plastic called edible film. The use of gadung tuber starch as a raw material for making edible films will not disturb food stability, because gadung is not consumed such as rice, corn and cassava. Gadung tubers are very good for edible film polymer materials containing high carbohydrates. Aim to determine the physical and chemical properties of the edible film starch of gadung tubers at various concentrations. The conclusion is that the optimum conditions for making edible films are good at 6\% starch concentration with KA $11.50 \%$ and an average thickness of $0.13 \mathrm{~mm}$.
\end{abstract}

Keywords: starch gadung; edible film; physico chemical properties; consentrations

\section{Pendahuluan}

Aktivitas manusia setiap hari tidak terlepas pada penggunaan plastik sebagai pembungkus makanan. Penggunaan plastik mempunyai keunggulan seperti ringan, kuat, transparan, tahan air, harganya relatif murah dan terjangkau oleh semua kalangan masyarakat. Namun, plastik yang beredar dipasaran merupakan polimer

\footnotetext{
${ }^{*}$ Penulis Korespondensi.

E-mail: asrawaty@unisapalu.ac.id

Telp: +62-81327226461
}

sintetik sulit didegradasi oleh mikroba tanah.

Kemasan plastik sering dimanfaatkan sebagai bahan pengemas makanan. Namun, penggunaan plastik dapat mencemari lingkungan, karena plastik sulit didegradasi secara alami. Menurut Krochta (1992), salah satu alternatif mengganti penggunaan plastik konvensional sebagai kemasan makanan adalah plastik berbahan alam yang mudah didegradasi (biodegradable plastic) yang disebut edible film.

Edible film merupakan lapisan tipis dan kontinyu, berasal dari bahan-bahan yang dapat 
dimakan, dibentuk di atas permukaan makanan (coating) atau diletakkan diantara lapisan makanan (film) berfungsi sebagai penghalang transfer massa (misalnya kelembaban, oksigen, lipid dan zat terlarut), sebagai pembawa bahan makanan serta dapat meningkatkan kemudahan penanganan makanan (Krochta, 1992). Contoh produk dari pengemasan edible film yaitu sosis daging yang bungkusnya ketika dimasak dan dimakan tidak perlu dibuang.

Penyusun edible film terdiri dari komponen utama yaitu hidrokoloid, lemak dan komposit (campuran hidrokoloid dan lemak). Hidrokoloid terdiri dari protein, turunan selulosa, alginat, pektin, pati dan polisakarida lain (Donhowe and Fennema, 1994). Jenis polisakarida merupakan bahan dasar, seperti pati sebagai bahan baku yang potensial pada pembuatan edible film yang memiliki karakteristik fisik mirip dengan plastik, tidak berbau, tidak memiliki rasa dan tidak berwarna (Thirathumthavorn and Charoenrein, 2007). Pati digunakan dalam industri pangan sebagai biodegradable film menggantikan polimer plastik disebabkan ekonomis, memberikan karakteristik fisik yang baik dan dapat diperbaharui (Bourtoom, 2008).

Pati terkandung pada tanaman yang banyak tumbuh melimpah dan beraneka ragam di Indonesia namun beberapa diantaranya belum dimanfaatkan, sehingga pati memiliki potensi besar menjadi salah satu alternatif bahan baku pembuatan edible film, umbi gadung sebagai salah satu sumber pati yang berpotensi atau dalam beberapa daerah di Sulawesi disebut dengan nama "Sikapa".

Umbi gadung (Dioscorin hispida Dennts) merupakan jenis umbi-umbian yang pemanfaatan belum dilakukan secara optimal oleh masyarakat. Selama ini umbi gadung masih dipandang sebelah mata bahkan dinilai tidak memiliki banyak manfaat. Hal ini dikarenakan umbi gadung merupakan anggota umbi-umbian yang mengandung senyawa racun berbahaya, seperti sianida dan senyawa alkaloid dioskorin. Namun disisi lain apabila diolah dengan baik, umbi gadung menghasilkan produk pangan yang dapat menunjang ketahanan pangan masyarakat, sebab umbi gadung sebagai sumber pati.

Penggunaan pati umbi gadung sebagai bahan baku pembuatan edible film tidak akan mengganggu kestabilan pangan, karena gadung tidak dikonsumsi seperti beras, jagung, dan singkong. Umbi gadung sangat baik digunakan untuk bahan polimer pada pembuatan edible film sebab mengandung karbohidrat yang cukup tinggi. Menurut Risnoyatiningsih (2011) karbohidrat memiliki peranan penting dalam menentukan karakter pada bahan makanan, berupa rasa, warna, tekstur, dan lain-lain. Penelitian Rastiyati $d k k$. (2016) menghasilkan jumlah karbohidrat dari pati umbi gadung sebesar $45,91 \%$. Berdasarkan hal tersebut, diharapkan umbi gadung dapat dibudidayakan oleh masyarakat sehingga dapat menjadi sumber mata pencaharian baru serta bahan baku untuk pembuatan edible film untuk mengatasi permasalahan pencemaran lingkungan. Penelitian ini bertujuan untuk mengetahui sifat fisik dan kimia edible film pati umbi gadung pada perbagai konsentrasi. Hasil penelitian ini dapat dijadikan sebagai bahan informasi terutama dikalangan akademik tentang penggunaan pati umbi gadung dalam proses pembuatan edible film. Hasil penelitian ini dapat pula dijadikan rujukan dan pembanding pada penelitian selanjutnya.

\section{Metode Penelitian}

\section{Bahan dan Alat}

Bahan yang digunakan untuk penelitian adalah pati dari umbi gadung, aquadest, dan gliserol, sedangkan bahan yang digunakan untuk analisis adalah silika gel, minyak zaitun, dan $\mathrm{NaCl}$.

Alat yang digunakan untuk penelitian adalah hot plate, beaker glass, timbangan, batang pengaduk, talang plastik, oven, dan thermometer. Alat yang digunakan untuk analisis adalah toples, erlenmeyer, rak dan tabung reaksi, neraca analitik, shacker, stopwatch, desikator, cawan porselin, cawan petri, gelas ukur, sentrifugasi, mechanical universal testing machine, gunting, kertas label, dan jangka sorong.

\section{Metode}

Penelitian ini dilakukan dengan menggunakan rancangan acak lengkap (RAL) satu faktor. Faktor yang dicobakan dalam penelitian ini ialah berbagai konsentrasi pati umbi gadung yang terdiri dari 6 taraf, yaitu:

$\mathrm{K} 1 \quad$ : Konsentrasi pati umbi gadung $1 \%$

K2 : Konsentrasi pati umbi gadung 2\%

K3 : Konsentrasi pati umbi gadung 3\%

K4 : Konsentrasi pati umbi gadung 4\%

K5 : Konsentrasi pati umbi gadung 5\%

K6 : Konsentrasi pati umbi gadung 6\%

Penelitian ini diulang 3 kali sehingga terdapat $6 \times 3=18$ unit percobaan. Untuk mengetahui pengaruh perlakuan yang dicobakan, maka dilakukan uji keragaman. Bila hasil uji keragaman menunjukkan pengaruh nyata, maka 
dilanjutkan dengan uji Beda Nyata Terkecil (BNT) $\alpha=0,05$ untuk mengetahui perbedaan antar perlakuan

\section{Pelaksanaan}

Pembuatan pati umbi gadung

a. Pengupasan dan pencucian

Bahan yang digunakan adalah umbi gadung diperoleh dari perkebunan. Selanjutnya umbi gadung tersebut dibersihkan dari sisa-sisa tanah dan kotoran yang menempel dengan cara mencucinya dengan air mengalir, kemudian dikupas dan dibersihkan kembali dengan air mengalir.

b. Penghancuran

Umbi gadung dipotong-potong hingga menjadi beberapa bagian ukuran kecil, pengecilan ukuran ini berfungsi untuk memudahkan proses selanjutnya yaitu penghancuran. Penghancuran umbi gadung untuk memperoleh bubur buah menggunakan blender dengan penambahan air. Pembagian air yang digunakan yaitu 3:1, dimana 1 bagian air digunakan saat menghancurkan umbi gadung dan 2 bagian air ditambahkan setelah diperoleh bubur buah.

c. Pemerasan dan pengendapan

Setelah bubur buah (filtrat) diperoleh, kemudian dilakukan pemerasan dengan menggunakan kain saring. Ampas dipisahkan dengan cairan pati yang keruh untuk kemudian diendapkan. Pengendapan dilakukan untuk memisahkan pati murni dari bagian lain seperti ampas yang masih tersisa. Pengendapan ini berlangsung selama 24 jam sampai air endapan menjadi jernih. Air endapan dikeluarkan dan diperoleh pati basah.

d. Pengeringan

Pengeringan berfungsi untuk menguapkan kandungan air sehingga diperoleh tepung yang kering. Pengeringan menggunakan sinar matahari dan dilakukan selama 8 jam. Jika kondisi cuaca tidak memungkinkan, maka akan dilanjutkan pengeringan panas buatan menggunakan suhu $50^{\circ} \mathrm{C}$ selama 3 jam.

e. Pengayakan

Gumpalan-gumpalan pati setelah dikeringkan langsung dihancurkan guna mendapatkan tepung yang diinginkan. Tepung tersebut kemudian diayak untuk memperoleh tepung yang halus dengan ayakan 80 mesh.

Pembuatan edible film

Pembuatan edible film diawali dengan membuat larutan pati umbi gadung sebagai perlakuan dengan konsntrasi $1 \%, 2 \%, 3 \%, 4 \%$,
$5 \%$ dan $6 \%(\mathrm{~b} / \mathrm{v})$. Kemudian ditambahkan gliserol $0,5 \mathrm{ml}$ sebagai plasticizer untuk menghindari atau mengurangi sifat rapuh film. Menurut Bourtoom (2008), edible film berbasis pati yang tidak ditambahkan plasticizer relatif lebih rapuh dan mudah hancur ketika dilepas dari cetakan. Larutan tersebut dipanaskan dalam hot plate stirrer sampai suhu mencapai $85^{\circ} \mathrm{C}$ selama 5 menit, hal ini dikarenakan pada suhu tersebut pati sudah tergelatinisasi untuk memperoleh larutan edible film. Sebelum dicetak, larutan tersebut didinginkan selama 10 menit agar gelembung-gelembung udara yang terdapat di dalamnya dapat hilang. Jika gelembunggelembung udara tersebut tidak dihilangkan, maka lapisan yang terbentuk akan mudah terdeformasi (rusak) karena terdapat pinhole di dalam lapisan.

Larutan pati umbi gadung dituang dalam plat plastik berukuran $22,6 \times 18 \times 3,7 \mathrm{~cm}$ dan diratakan untuk menjaga agar ketebalan film tetap sama, selanjutnya dikeringkan dalam oven pada suhu $50^{\circ} \mathrm{C}$ selama 10 jam. Pengeringan dihentikan setelah film mudah dilepas dari plat. Setelah kering, didinginkan pada suhu ruang selama 15 menit, film kemudian dilepas dari plat.

\section{Pengamatan}

Untuk mengetahui pengaruh perlakuan yang dicobakan, maka dilakukan analisis terhadap komponen hasil pengolahan yang meliputi:

Kadar air (AOAC, 1990)

Untuk mengetahui kadar air pada bahan dapat digunakan metode pengovenan. Cawan kosong dibersihkan, lalu diberi label kemudian dipanaskan didalam oven pada suhu $105^{\circ} \mathrm{C}$ selama 15 menit setelah itu ditimbang. Sampel yang telah dihaluskan ditimbang di dalam cawan sebanyak 2,5 g. Cawan beserta isinya dipanaskan di dalam oven pada suhu $105^{\circ} \mathrm{C}$ selama 2 jam lalu dipindahkan ke dalam desikator untuk didinginkan kemudian ditimbang. Dipanaskan kembali di dalam oven hingga memperoleh berat yang konstan. Nilai kadar air bahan dapat diperoleh melalui persamaan;

Kadar Air $(\%)=\frac{(\mathrm{BS}+\mathrm{BCK})-(\mathrm{BCK}+1)^{*}}{-\mathrm{BS}}$

Keterangan:

$\begin{array}{lll}\mathrm{BCK} & = & \text { Berat cawan kosong } \\ (\mathrm{BCK}+1)^{*} & = & \text { Berat cawan dengan isi } \\ \text { setelah dioven } & & \\ \mathrm{BS} & = & \text { Berat sampel }\end{array}$


Ketebalan (Turhan \& Sabhaz, 2004)

Uji ketebalan edible film diukur dengan jangka sorong, dengan cara menempatkan film diantara rahang jangka sorong. Ketebalan diukur dengan menumpuk 10 lembar sampel yang telah dipotong dengan ukuran $1 \times 1 \mathrm{~cm}$, kemudian dihitung reratanya.

Laju transmisi uap air (water vapor transmission rate) (Xu et al., 2005)

Permeabilitas uap air merupakan jumlah uap air yang hilang per satuan waktu dibagi dengan luas area film. Salah satu fungsi edible film adalah untuk menahan migrasi uap air, maka permeabilitasnya terhadap uap air harus serendah mungkin (Gontard, 1993). Membuat larutan garam jenuh dalam suatu chamber, yaitu wadah toples untuk membuat $\mathrm{RH} 75 \%$ yaitu dengan melarutkan $40 \%$ garam $\mathrm{NaCl}(\mathrm{b} / \mathrm{v}$ ) atau $100 \mathrm{~g}$ $\mathrm{NaCl}$ dalam $250 \mathrm{ml}$ aquades. Ukuran toples adalah diameter $12 \mathrm{~cm}$ dan tinggi $15 \mathrm{~cm}$, diletakkan pada suhu ruang. Siapkan cawan akrilik dengan silica gel sebanyak $10 \mathrm{~g}$, sedangkan film digunting selebar cawan. Sampel film diletakkan di atas cawan, lalu dikencangkan bautnya. Ukuran cawan aklirik dengan diameter 5 $\mathrm{cm}$ dan kedalaman $1,8 \mathrm{~cm}$.

Cawan yang sudah ditutup dengan film ditempatkan pada chamber yang sudah diatur RHnya. Uap air terdifusi melalui film akan diserap oleh silica gel sehingga menambah berat silica gel. Penimbangan cawan beserta film dan silica gel dilakukan setiap jam selama 7-8 jam untuk mengetahui pertambahan berat. Data yang diperoleh dibuat grafik hubungan antara waktu dan berat, kemudian ditentukan slopenya. WVTR ditentukan dengan persamaan:

$$
\text { WVTR }=\frac{\text { slope kenaikan berat cawan }\left(\frac{\mathrm{g}}{\mathrm{jam}}\right)}{\text { luas permukaan film }\left(\mathrm{m}^{2}\right)}
$$

Daya menahan air (water holding capacity) dan daya menahan minyak (oil holding capacity)

Tabung reaksi dibersihkan lalu dioven selama 1 jam, kemudian dimasukkan ke dalam desikator hingga tabung dingin. Tabung reaksi kosong ditimbang menggunakan neraca analitik dan dicatat beratnya, kemudian sampel ditimbang sebanyak $0,25 \mathrm{~g}$ dan dimasukkan ke dalam tabung reaksi, selanjutnya ditambahkan dengan aquades sebanyak $10 \mathrm{ml}$ ke dalam tabung reaksi yang telah berisi sampel. Diaduk menggunakan shacker hingga air dan sampel larut. Sampel yang telah dilarutkan didiamkan selama 1 jam pada suhu kamar, lalu disentrifugasi selama 20 menit untuk memisahkan endapan dan ditimbang kembali. Ulangi langkah tersebut untuk pengujian daya serap minyak. Pada uji daya serap minyak menggunakan minyak zaitun. Adapun rumus perhitungan daya serap air dan minyak sebagai berikut:

Daya serap air atau minyak $(\mathrm{g} / \mathrm{g})$

$$
=\frac{(\mathrm{BT}+1) *-\mathrm{BTK}}{\mathrm{BS}}
$$

Keterangan:

$(\mathrm{BT}+1)^{*}=$ Berat tabung dengan isi setelah

disentrifuge

BTK= = Berat tabung kosong

BS = Berat sampel

\section{Hasil dan Pembahasan}

\section{Kadar air (\%)}

Kadar air edible film pada perlakuan berbagai konsentrasi pati umbi gadung menunjukkan bahwa perlakuan berbagai konsentrasi pati umbi gadung berpengaruh nyata terhadap kadar air edible film. Adapun data ratarata kadar air edible film dapat dilihat pada Gambar 1.

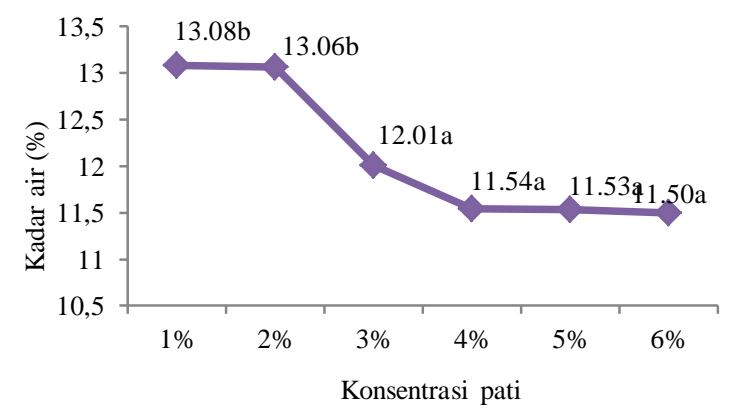

Gambar 1. Data rata-rata kadar air edible film pada berbagai konsentrasi pati umbi gadung

Pati umbi gadung konsentrasi 6\% memberikan hasil yang lebih baik dengan kadar air paling rendah (rata-rata $11,50 \%$ ) meskipun berbeda tidak nyata dengan perlakuan 3\%, 4\% dan $5 \%$, tetapi berbeda nyata dengan perlakuan konsentrasi $1 \%$ dan 2\%. Berdasarkan hasil tersebut, dapat dilihat bahwa semakin tinggi konsentrasi pati umbi gadung, semakin rendah kadar air edible film, demikian pula sebaliknya semakin rendah konsentrasi pati umbi gadung, semakin tinggi kadar air edible film yang dihasilkan.

Kadar air edible film menurun seiring dengan semakin tingginya konsentrasi pati umbi gadung yang ditambahkan. Peningkatan konsentrasi pati akan meningkatkan jumlah polimer yang menyusun matrik film. Menurut Amaliya dan Putri (2014), semakin besar polimer 
yang menyusun matrik film, maka akan meningkatkan jumlah padatan sehingga jumlah air dalam edible film semakin rendah.

Rendahnya kadar air dari edible film tersebut menunjukan bahwa film itu baik dan bisa melindungi produk yang dikemas. Tinggi rendahnya kandungan kadar air dalam edible film dipengaruhi dari bahan dasar, juga bahan yang ditambahan pada pembuatan film (Salimah $d k k$., 2016). Syarat mutu edible film menurut SNI 063735-1995 adalah memiliki kadar air maksimum $16 \%$.

\section{Ketebalan (mm)}

Ketebalan edible film pada perlakuan berbagai konsentrasi pati umbi gadung dengan berbagai jumlah konsentrasi pati umbi gadung tentunya berpengaruh pada nyata bagi ketebalan edible film itu. Adapun data rata-rata ketebalan edible film dapat dilihat pada Gambar 2.

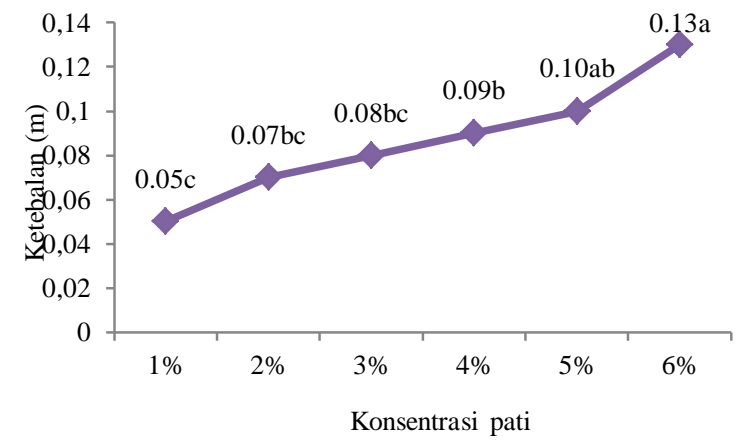

Gambar 2. Data rata-rata ketebalan edible film pada berbagai konsentrasi pati umbi gadung

Ketebalan edible film merupakan hal penting, menentukan kelayakan bagi film tersebut sebagai pegemas produk pangan karena ketebalan bisa mempengaruhi sifat fisik dan kimia edible film, seperti pemanjangan, kuat tarik, daya larut dan permeabilitas uap air. Dengan tebalnya suatu edible film tentunya akan memberi perlindungan yang lebih baik kepada produk yang dikemasnya namaun permeabilitas uap airnya akan semakin besar. Semakin tebal edible film akan meningkatkan kuat tariknya, namun daya larut dalam air dan nilai pemanjangnya akan menurun. (Ariska dan Suyatno, 2015). Standar ketebalan edible film menurut Japanese Industrial Standard dalam Krochta et al., (1994) yaitu maksimum 0,25 mm.

Pati umbi gadung konsentrasi 6\% memberikan hasil yang lebih baik dengan ketebalan edible film paling tinggi (rata-rata $0,13 \mathrm{~mm}$ ) meskipun tidak berbeda nyata dengan perlakuan 5\% namun menunjukan perbedaan nyata dengan yang lainnya. Berdasarkan hasil tersebut, dapat dilihat bahwa semakin tinggi konsentrasi pati umbi gadung, semakin tinggi ketebalan edible film, demikian pula sebaliknya semakin rendah konsentrasi pati umbi gadung, semakin rendah ketebalan edible film yang dihasilkan.

Pada penelitian ini terlihat bahwa semakin banyak konsentrasi komponen yang menyusun, dapat meningkatkan total padatan terlarut, sehingga menambah ketebalan dari edible film. Harris (2001) kalau konsentrasi bahan yang dipakai(pati) ditingkatkan maka akan meningkan total padatan pada edibe film setelah dikeringkan, sehingga akan menghasilkan film yang semakin tebal. Menurut hasil penelitian Amaliya dan Putri (2014), menyatakan bahwa semakin banyak pati jagung yang digunakan akan menyebabkan struktur penyusun polimer akan menjadi lebih banyak sehingga aka menghasilkan film yang makin tebal, semakin tinggi konsentrasi polimer penyusunnya pada batas tertentu mampu meningkatkan ketebalan dan stabilitas edible film (Guilbert and Biquet, 1990).

\section{Laju Transmisi Uap Air (Water Vapor Transmission Rate)}

Laju transmisi uap air edible film pada perlakuan berbagai konsentrasi pati umbi gadung berpengaruh tidak nyata terhadap laju transmisi uap air edible film. Adapun data rata-rata laju transmisi uap air edible film dapat di lihat pada gambar 3 .

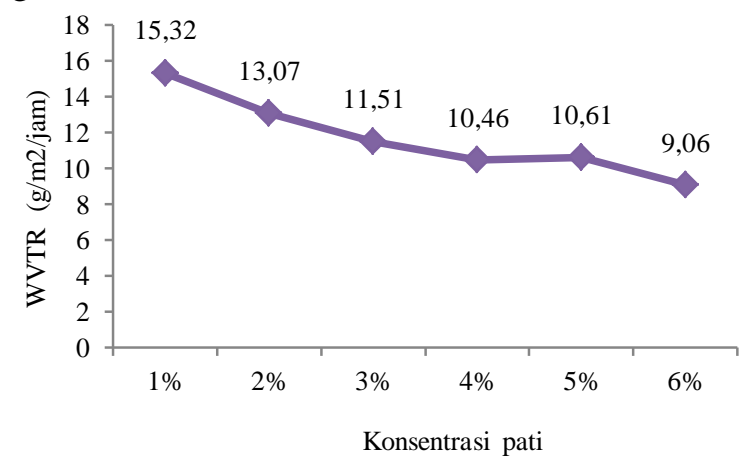

Gambar 3. Data rata-rata laju tranmisi uap air edible fillm pada berbagai konsentrasi pati umbi gadung

Laju transmisi uap air adalah pengukuran dari mudahnya uap air melalaui suatu bahan tanpa memperhitungkan ketebalan bahan dan tekanan udara baik di dalam dan di luar bahan (Pudjiastuti, dkk., 2013). Edible film yang baik apabilah tidak mudah dilewati oleh uap air atau mempunyai laju transmisi uap air yang rendah. Film yang baik adalah film yang memiliki WVTR seminimal mungkin. Krochta et al., (1994) menjelaskan bahwa batas standar maksimum laju 
transmisi uap air menurut Japanese Industrial Standard yaitu $10 \mathrm{~g} / \mathrm{m}^{2}$.

Meskipun tidak berpengaruh nyata pada analisi ragam, namun dapat dilihat peningkatan konsentrasi pati umbi gadung cenderung dapat menurunkan laju transmisi uap air dari edible film, dimana laju transmisi uap airnya mencapai $9,06 \mathrm{~g} / \mathrm{m}^{2} / \mathrm{jam}$. Menurut Rahim $d k k$. (2010), hasil demikian itu karena tingginya konsentrasi pati yang digukan sehingga kadar amilosa bertambah yang bisa meningkatkan jumlah ikatan antar molekul pati sehingga menurunkan permeabilitas tersebut. Hal ini juga diduga karena kuatnya ikatan antar rantai polimer sehingga permeabilitas uap airnya jadi menurun.

Meningkatnya daya ikat antar polimer akan menurunkan transmisi uap air edible film terhadap gas, uap dan porositasnya, sehingga fungsi edible film sebagai penghalang masuknya uap air akan meningkat (Pramadita dan Citraning, 2011). Selanjutnya Amaliya dan Putri (2014) menjelaskan, terbentuknya ikatan hidrogen maka akan meningkatkan jumlah matriks film yang terbentuk sehingga menurunkan laju transmisi uap air pada edible film.

Transmisi uap air tentunya sangat dipengruhi oleh aktivitas air (aw), RM, temperatur, ketebalan, jenis dan konsentrasi plasticizer, dan sifat bahan pembentuk edible film. Pada umumnya bahwa bahan yang terbuat dari bahan protein dan polisakarida mempunyai nilai transmisi uap air yang tinggi. Hal ini dikarenakan bahan tersebut merupakan polimer polar dan juga memiliki ikatan hidrogen yang besar sengga menghasilkan penyerapan air pada kondisi lembaban (RH) yang tinggi. Hal ini juga menyebabkan terganggunya interaksi rantai intermolekuler yang disebabkan oleh penyerapan air tersebut (Krochta, et al., 1994).

\section{Daya Menahan Air (Water Holding Capacity)}

Daya menahan air edible film pada perlakuan berbagai konsentrasi pati umbi gadung berpengaruh tidak nyata. Adapun data rata-rata daya menahan air edible film dapat dilihat pada Gambar 4.

Daya menahan air atau Water Holding Capacity (WHC) diartikan sebagai kemampuan untuk mengikat air yang ada dalam bahan maupun yang ditambahkan selama proses pengolahan dan kemampuan dari bahan untuk bisa menahan air. WHC juga dapat dihubungkan dengan besarnya daya tarik-menarik air.

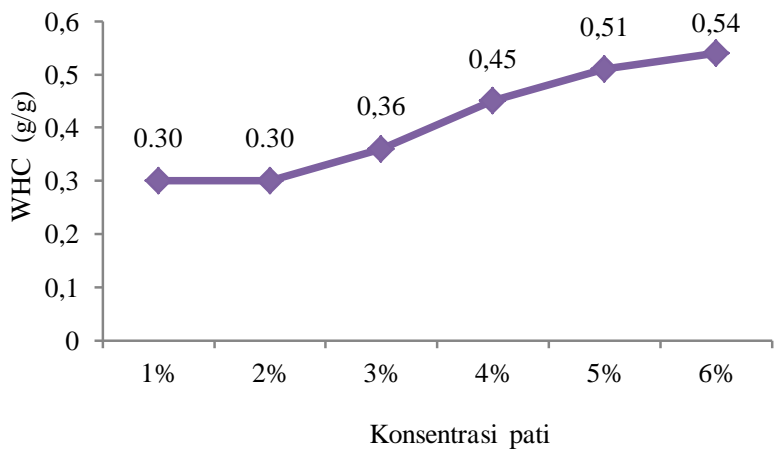

Gambar 4. Data rata-rata daya menahan air edible film pada berbagai konsentrasi pati umbi gadung

Hasil penelitian Gambar 4 menunjukkan bahwa meskipun tidak berpengaruh nyata pada analisis ragam, namun dapat dilihat peningkatan konsentrasi pati umbi gadung cenderung dapat meningkatkan daya menahan air edible film. Nilai rata-rata daya menahan air edible film yang dihasilkan adalah $0,30 \mathrm{~g} / \mathrm{g}$ pada konsentrasi pati $1 \%$ dan cenderung meningkat hingga $0,54 \mathrm{~g} / \mathrm{g}$ pada konsentrasi pati $6 \%$.

Kelarutan film dalam air dapat disebabkan beberapa factor, diantaranya menurut Schmidt et al. (2013) adalah interaksi antara komponenkomponen pembentuk matriks film seperti komponen yang bersifat hidrofilik dan hidrofobik serta struktur film yang dihasilkan. Mahmoud and Savello (1992) dalam Pangesti (2014) menambahkan bahwa daya ikat air dari gliserol yang ditambahkan bisa meningkatkan daya menahan air dari edible film itu. Menurut Mahmoud and Savello (1992) dalam Awwaly $d k k$. (2010), gleserol merupakan plasticizer hidrofilik yang mampu memperpanjang, menambah air dan mengendurkan struktur film. Dengan begitu gliserol mampu meningkatkan WHC dan penyebaran air.

\section{Daya Menahan Minyak (Oil Holding Capacity)}

Daya menahan minyak edible film pada perlakuan berbagai konsentrasi pati umbi gadung menunjukkan bahwa perlakuan berbagai konsentrasi pati umbi gadung berpengaruh tidak nyata terhadap daya menahan minyak edible film. Adapun data rata-rata daya menahan minyak edible film dapat dilihat pada Gambar 5 


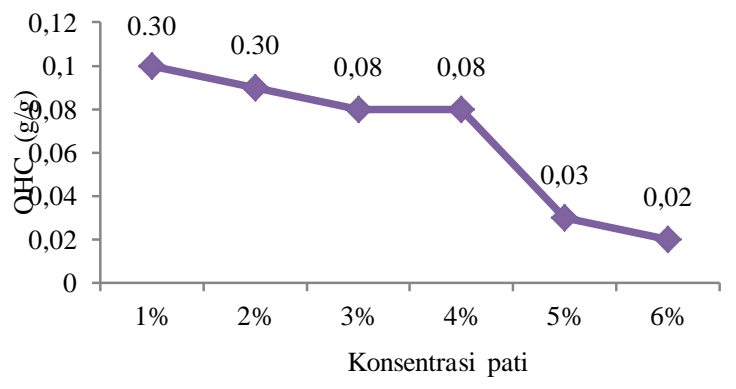

Gambar 5. Data rata-rata daya menahan minyak edible film pada berbagai konsentrasi pati umbi gadung

Daya menahan minyak atau Oil Holding Capacity (OHC) adalah suatu ukuran dari jumlah minyak yang mampu diserap oleh matrik dari bahan pangan. Hasil penelitian Gambar 5 menunjukkan bahwa peningkatan konsentrasi pati umbi gadung cenderung dapat menurunkan daya menahan minyak pada edible film. Nilai rata-rata daya menahan minyak yang dihasilkan adalah $0,30 \mathrm{~g} / \mathrm{g}$ pada konsentrasi pati $1 \%$ dan cenderung menurun hingga $0,02 \mathrm{~g} / \mathrm{g}$ pada konsentrasi pati $6 \%$.

Hasil penelitian ini menunjukan bahwa semakin tinggi konsentrasi pati yang diberikan maka daya menahan minyak cenderung menurun. Hal ini disebabkan granula pati umbi banggai dapat menarik air lebih banyak dibandingkan minyak. Pembuatan edible film dari pati memiliki kemampuan yang baik untuk melindungi produk terhadap oksigen, karbondioksida, minyak dan meningkatkan kesatuan produk (Warkoyo $d k k$., 2014). Pati memiliki bagian lipofilik, itu ditunjukan dengan memampuannya menyerap minyak. Menurut Rahim dkk. (2019), protein yang terdapat pada permukaan granula pati juga mempengaruhi daya serap minyak. Protein bisa membentuk kompleks yang bisa memberi tempat terikatnya minyak pada pati.

\section{Kesimpulan}

Penelitian ini menunjukan bahwa kondisi optimum pada pembuatan edible film yang baik terdapat pada perlakuan konsentrasi pati umbi gadung $6 \%$ dengan sifat fisik dan kimia yaitu kadar air rata-rata $11,50 \%$ dan ketebalan rata-rata $0,13 \mathrm{~mm}$

\section{Daftar Pustaka}

AOAC, 1990. Official Methods of Analysis. Association of Official Analytical Chemist, Washington
Amaliya, R.R. dan W.D.R. Putri, 2014. Karakterisasi Edible Film dari Pati Jagung dengan Penambahan Filtrat Kunyit Putih Sebagai Antibakteri. Jurnal Pangan dan Agroindustri Vol.2(3):43-53

Ariska RE. dan Suyatno, 2015. Pengaruh Konsentrasi Karagenan terhadap Sifat Fisik dan Mekanik Edible Film dari Pati Bonggol Pisang Dan Karagenan dengan Plasticizer Gliserol. Prosiding. Seminar Nasional Kimia Jurusan Kimia FMIPA Universitas Negeri Surabaya. Surabaya, 3-4 Oktober 2015.

Awwaly, K.U., A. Manab dan E. Wahyuni, 2010. Pembuatan Edible Film Protein Whey: Kajian Rasio Protein dan Gliserol terhadap Sifat Fisik dan Kimia. Jurnal Ilmu dan Teknologi Hasil Ternak, Vol. 5(1): 45-56.

Bourtoom, T., 2008. Plasticizer Effect on The Properties of Biodegradable Blend Film From Rice Starch-Chitosan. Songklanakarin J, Sci, Technol, Vol 30 (Suppl,1), 149-165.

Donhowe, I.G. dan O. Fennema, 1994. Edible Films and Coatings Characteristics, Formation, Definitions, and Testing Methods. Academic Press Inc. London.

Harris, H., 2001. Kemungkinan Penggunaan Edible Film dari Pati Tapioka Untuk Pengemas Lempuk. Jurnal Ilmu-ilmu Pertanian Indonesia.Vol.

Krochta, J.M., Baldwin E.A., Nisperos-Carriedo M.O., 1994. Edible Coatings and Films to Improve Food Quality. Technomic Publication. Co. Inc, USA.

Pramadita dan R. Citraning, 2011. Karakterisasi Edible Film dari Tepung Porang (Amorphophallus Oncophyllus) dengan Penambahan Minyak Atsiri Kayu Manis (Cinnamon Burmani) sebagai Antibakteri. Skripsi. Jurusan Teknologi Hasil Pertanian Fakultas Teknologi Pertanian Universitas Brawijaya, Malang

Pudjiastuti, W., A. Listyarini dan M.I. Rizki, 2013. Pengaruh Laju Transmisi Uap Air Polymer Blend Polibutilen Suksinat (PBS) dan Linear Low Density Polyethylene (LLDPE) terhadap Umur Simpan Sup Krim Instan Rasi. J. Kimia Kemasan, Vol.35(1): $1-5$

Rahim, A., N. Alam, Haryadi dan U. Santoso, 2010. Pengaruh Konsentrasi Pati Aren dan Minyak Sawit terhadap Sifat Fisik dan 
Mekanik Edible Film. J. Agroland 17 (1): $38-46$

Rahim, A., Sukmawati, S. Kadir, Jusman, Rahmi dan If'all, 2019. Karakteristik Fisikokimia Pati Aren Asetat Fosfat pada Berbagai Konsentrasi Natrium Trimetafosfat dan Tripolifosfat. B. Palma Vol. 20(2): 119-125

Salimah T., W.F. Ma'ruf, Romadhon, 2016. Pengaruh Transglutaminase Terhadap Mutu Edible Film Gelatin Kulit Ikan Kakap Putih (Lates calcalifer). J. Peng. \& Biotek. Hasil Pi. Vol. 5(1): 49-55
p-ISSN : 2527-5631

Thirathumthavorn, D. and S. Charoenrein, 2007. Aging Effect On-And Noncrystallizing Sorbitol-Plasticized Tapioca Starch Films. Starch 59:493-497.

Warkoyo, B. Rahardjo, D.W. Marseno, J.N.W. Karyadi, 2014. Sifat Fisik, Mekanik dan Barrier Edible Film Berbasis Pati Umbi Kimpul (Xanthosoma sagittifolium) yang Diinkorporasi dengan Kalium Sorbat. Agritech Vol. 34(1): 72-81 